\title{
Production of Microbial Enzymes from Ripe Plantain Fruits
}

\author{
K. J. Mogaji* and O. Mogaji \\ Federal School of Medical Laboratory Technology, Jos, Nigeria \\ *Corresponding author
}

\section{Keywords}

Microbial enzymes, Fermentation period,

Morphology,

Catalogue,

Metabolites

Article Info

Accepted:

30 May 2020

Available Online:

10 June 2020

\section{A B S T R A C T}

Microbial enzymes have significant biotechnological application in industries. The purpose of this study was to isolate and identify microorganisms associated with ripe plantain fruits, determine the enzyme activity (lipase, protease, pectinase, cellulase and amylase) of the ripe plantain fruits samples and screen the isolated microorganisms for enzyme production. For isolation, standard isolation method was followed, while screening was done on different agar medium. Results revealed that. Day 5 of the fermentation period has the highest enzyme activity for all the enzymes in the fermented plantain fruit; lipase has the highest enzyme activity with a value of $1.3485 \mathrm{mg} / \mathrm{mL} / \mathrm{min}$ while pectinase has the lowest with a value of $0.0014 \mathrm{mg} / \mathrm{mL} / \mathrm{min}$. Bacillus spp were screened positive for all the enzymes assayed for. Microorganisms were identified according to colony morphology and microscopic observation. This study contributes to catalogue of microorganisms that has been identified as enzyme producers and provides additional information to support future research about the industrial potential of these microorganisms that may produce enzymes and other metabolites of industrial importance.

\section{Introduction}

Plantain (Musa paradiasiaca) is an important staple starchy food in Nigeria, which belong to the family of Musaceae. It is a monocotyledonous, perennial fruit cultivated in the tropical and sub - tropical regions of the world (Stresses et al., 2006). It is highly perishable fruit, which can be available all year round. The large quantity of plantains provides the potential for industrial use. Plantain fruits are a great source of lignocellulosic biomass which is renewable, chiefly unexploited and inexpensive. It has a lot of nutritional benefits accounting to its high demand in the market. They are used as food, beverages, fermentable sugars, medicines and flavouring (Nelson et al., 2006). Plantains contribute to a healthy and balanced diet, providing a rich source of 
vitamins and mineral to fuel the body. Plantain is composed mainly of water (around 75 percent) and carbohydrates (32percent). Carbohydrate in plantain is made up of the sugars and starches. The sugars and starches that make up this fraction are present in varying concentrations according to the state of the fruit's ripeness (FAO, 2014). The major change during the ripening process of plantain is the conversion of starch to sugar.

Many microorganisms such as bacteria, mould, and yeast produce a collection of multipurpose enzymes with extensive diversity of structures and industrial applications. Many microbial enzymes, such as amylases, cellulases, lipases, pectinases and proteases extracellularly produced. Amylases, starch-degrading enzymes, have numerous biotechnological applications. These enzymes are used in textile and garments, paper industries, starch liquefaction, food, adhesive and sugar production and pharmaceuticals (Bajpai et al., 1989). Cellulases, sugar degrading enzymes are used in textile industry for bio-polishing of fabrics and producing stonewashed look of denims, as well as in household laundry detergents for improving fabric softness and brightness (Hill et al., 2006). Besides, they are used in animal feeds for improving the nutritional quality and digestibility, in processing of fruit juice and in baking, while de-inking of paper is yet another emerging application (Sangrila et al., 2013).

Lipases, lipid degrading enzyme are versatile tool for biotechnology. It is applicable in multiple industries such as agrochemical, pharmaceutical, cosmetic and perfume, taste and flavor industries, textile, food and dairy, detergent and surfactant industries, fat and oil, leather and paper production, chemical and waste water treatment et al., . Especially lipases are applied for biodiesel production (Hasan et al., 2006). Pectinases a group of enzymes that contribute to the degradation of pectin by various mechanisms. Acidic pectic enzymes are widely used in the production and clarification of fruit juices and wines (Rachana, 2017).

They are also very important in maceration and solubilization of fruit pulps. Alkaline pectic enzymes have been used in several areas, including retting and degumming of fiber crops, textile processing, coffee and tea fermentations, paper and pulp industry, and oil extraction (Kiro, 2010). Proteases, enzyme which catabolizes protein by hydrolysis of peptide bonds are generally used in detergents, food industries meat processing, cheese making, silver recovery from photographic film, production of digestive and certain medical treatments of inflammation and virulent wounds. They also have medical pharmaceutical applications (Hamid et al., 2008). The increase in world enzyme demand has led to sourcing for alternative substrate for the production of microbial enzyme; hence, agricultural wastes are readily accessible around the world as residual wastes for the production of these enzymes.

\section{Materials and Methods}

\section{Collection of sample}

Unripe mature plantain fruits (Musa paradiasca, Linn) were obtained from a farmland in Arigidi Akoko, Ondo State, Nigeria. The plantain fruits were kept in a sterile air tight polythene bags and transported to the Microbiology Postgraduate Laboratory, Federal University of Technology, Akure for further analysis.

\section{Ripening of plantain}

Unripe plantain fruits were made ripened naturally for 9 days. 


\section{Preparation of plantain fruits}

The ripened plantain fruits were washed under running water to remove dirt, peeled and grinded using an electric blender (Model QBL-18L40). The grinded plantain fruits were divided into two portions; $\mathrm{A}$ and $\mathrm{B}$. Portion A was left unfermented while Portion $\mathrm{B}$ was fermented for 5 days.

\section{Isolation of bacteria and fungi from samples}

Serial dilution was done to reduce the microbial population. One millilitre $(1 \mathrm{ml})$ aliquot of the fermented sample and $1 \mathrm{~g}$ of the unfermented sample were separately transferred into $9 \mathrm{ml}$ of sterile distilled water in a test tubes. At every 24 hours, samples were aseptically withdrawn from the fermentors, serially diluted. A stepwise serial dilution was carried out until the required dilution was obtained. A $1 \mathrm{ml}$ aliquot $\left(10^{-6}\right.$ and $10^{-4}$ dilution factors for bacteria and fungi isolation respectively). Nutrient agar (NA), nutrient broth (NB), Potato dextrose agar (PDA), Potato dextrose broth (PDB) were prepared according to manufacturer's specification for the isolation of bacteria and fungi. Nutrient agar and potatoes dextrose agar was prepared for bacteria and fungi respectively. The media after cooling down were aseptically poured in Petri dishes under laminar flow hood using pour plate technique and allowed to solidify. Samples were aseptically introduced into the Petri dishes using sterile pipette. The plates were later incubated at $37^{\circ} \mathrm{C}$ for 24 hours for bacteria and $25^{\circ} \mathrm{C}$ for 72 hours for fungi. After 24 hours of incubation, the plates were examined for bacteria. Colonies and spore forming units formed on the media were counted and subcultured on freshly prepared nutrient agar media to obtain pure culture of bacteria. Thereafter, the plates were incubated at $37^{\circ} \mathrm{C}$ for 24 hours. The pure isolates were stored temporarily on slants and kept at $4^{0} \mathrm{C}$ for further use (Fawole and Oso, 2007), while after 72 hours of incubation, the plates were examined for fungi on potato dextrose agar. Isolates were sub-cultured on freshly prepared potato dextrose agar media to obtain pure culture. Thereafter, the plates were incubated at $25^{\circ} \mathrm{C}$ for 72 hours (Cheesbrough, 2010). The Bacteria isolate were observed using microscopy, Gram staining, sugar fermentation test, biochemical tests such as urease test, catalase test, citrate utilization test and indole test while the morphological, cultural and microscopy identification of fungi isolates was examined based on the colour, types and shapes of spores, conodia and hyphae; further stained with two drops of lactophenol-cotton blue dye and viewed under light microscope (Fawole and Oso, 2007).

\section{Enzyme activity}

The enzyme activity of both the unfermented and fermented ripe plantain fruits sample was determined using the techniques for cellulase, protease, lipase, pectinase and amylase respectively according to the method of (Bernfeld, 1951; Miller, 1959; Ladd and Butler, 1972; Mandels et al., 1976; Maia et al., 1999)

\section{Microbial screening for enzyme production}

Culture media specific to each enzyme were used for primary screening of enzymes production by following the methods for cellulase, protease, lipase, pectinase and amylase respectively according to the method of (Hankin, et al., 1971; Akpomie et al., 2012; Lisdiyanti et al., 2012; Saowapar et al., 2014; Hnin et al., 2015; Toshi and Sudhir, 2017).

\section{Statistical analysis}

The experimental design was done in triplicate. The data obtained were subjected to one way analysis of variance (ANOVA) SPSS 
version 2.0. Differences were considered significant at $\mathrm{P}<0.05$.

\section{Results and Discussion}

\section{Microbial isolation and identification}

The total bacterial counts $\left(10^{6} \mathrm{cfu} / \mathrm{ml}\right)$, fungal mean counts $\left(10^{4} \mathrm{sfu} / \mathrm{ml}\right)$ is shown in Figure 1 and 2. The total bacterial count in the unfermented sample was 10.21 , while that of fungi was 16.00. The total bacterial counts for the fermented sample ranged from 13.11 to 38.01 , while the range for fungi was 21.2238.00. The identified bacteria isolate from ripe plantain fruits during fermentation include; Escherichia coli, Staphylococcus aureus, Bacillus subtilis, Bacillus cereus, Lactobacillus plantarum, Leuconostoc mesenteriodes, Streptococcus feacalisand Lactobacillus fermentum. The Moulds identified during fermentation include; Aspergillus niger, Aspergillus flavus and Penicillium notatum. Saccharomyces cerevisaeand Candida utilis were the yeasts isolated during fermentation as presented in tables 1, 2 and 3 respectively.

\section{Enzyme activity and microbial screening for enzyme Production}

The enzyme activity $(\mathrm{mg} / \mathrm{ml} / \mathrm{min})$ of the unfermented sample and the fermented plantain fruit sample is represented in figure 3 . The highest cellulase activity was on day 5 (0.6940) of the fermentation period. The enzyme activities for all the enzymes assayed for were low in the unfermented sample. Among all the assayed enzymes, lipase showed the highest enzyme activity. All the isolated microorganisms exhibited one or more enzymatic activity. Bacillus spp exhibited enzyme activity to all the enzymes. Bacillus spp were the only bacteria that exhibited pectinase activity, while all the fungi except $C$. albicans and Penicillumi notatum exhibited pectinase activity. All the isolate exhibited amylase activity (Table 5).

The lignocellulosic structure of plantain fruits may be a factor responsible for the low microbial population in the unfermented sample (Agbor et al., 2011; Akhtar et al., 2012). The presence of bacteria such as $B$. cereus, and B. subtilis in the unfermented sample agrees with the findings of Oriola $e t$ al., (2017) when plantain fruits were fermented for 3 days during production of "Agadagidi." The presence moulds such as $A$. niger, A. flavus and $P$. notatum in the unfermented sample could be a result of them being plantain fruits microflora which agrees with the finding of Oriola et al., (2017) when A. flavusA. fumigatus and $P$. notatum were isolated from uncrushed plantain fruits. The dominant population of $A$. flavus particularly in the unfermented sample may be due to the presence of nutrients available within the plantain fruits for utilization. Nasrin et al., (2017) attested to this when combination of molasses and jackfruit were used as a substrate for mutant strain of A. niger for citric acid production. Slightly acidic environment of the plantain fruts may be responsible fortheir adaptation (Murali et al., 2017).

Lactobacillus spp are vital organisms for fermentation process which may be responsible for their presence from during fermentation. Kalui and co-researchers (2010) documented in a review that these bacteria are essential in spontaneously fermenting food and that these microorganisms produce lactic acid as an important product from the energy yielding fermentation of sugars. These conditions created by Lactobacillus spp could favour the growth of fungi particularly on day 4 and beyond, thus, Fungi, Lactobacillus metabolise sugars within the plantain fruits which is converted to organic acids. 
Table.1 Morphological and biochemical characteristics of bacteria isolated during fermentation of ripe plantain fruits

\begin{tabular}{|l|c|c|c|c|c|c|c|c|c|}
\hline & A & B & C & D & E & F & G & H \\
\hline Colour & Cream & Pale yellow & White & White & Yellow & Cream & White & White \\
\hline Shape & Rod & Cocci & Rod & Rod & Cocci & Rod & Cocci & Rod \\
\hline Edge & Entire & Entire & Irregular & Irregular & Entire & Irregular & Entire & Irregular \\
\hline Elevation & Flat & Raised & Flat & Flat & Raised & Circular & Circular & Circular \\
\hline Surface & Rough & Smooth & Smooth & Rough & Smooth & Smooth & Smooth & Smooth \\
\hline Gram & $-\mathrm{ve}$ & $+\mathrm{ve}$ & $+\mathrm{ve}$ & $+\mathrm{ve}$ & $+\mathrm{ve}$ & $+\mathrm{ve}$ & $+\mathrm{ve}$ & $+\mathrm{ve}$ \\
\hline Catalase & $+\mathrm{ve}$ & $+\mathrm{ve}$ & $+\mathrm{ve}$ & $+\mathrm{ve}$ & $-\mathrm{ve}$ & $-\mathrm{ve}$ & $-\mathrm{ve}$ & $-\mathrm{ve}$ \\
\hline Coagulase & $+\mathrm{ve}$ & $-\mathrm{ve}$ & $-\mathrm{ve}$ & $-\mathrm{ve}$ & $-\mathrm{ve}$ & $-\mathrm{ve}$ & $-\mathrm{ve}$ & $-\mathrm{ve}$ \\
\hline Spore & $-\mathrm{ve}$ & $-\mathrm{ve}$ & $+\mathrm{ve}$ & $+\mathrm{ve}$ & $-\mathrm{ve}$ & $-\mathrm{ve}$ & $+\mathrm{ve}$ & $-\mathrm{ve}$ \\
\hline Motility & $+\mathrm{ve}$ & $+\mathrm{ve}$ & $+\mathrm{ve}$ & $+\mathrm{ve}$ & $-\mathrm{ve}$ & $-\mathrm{ve}$ & $-\mathrm{ve}$ & $-\mathrm{ve}$ \\
\hline Oxidase & $-\mathrm{ve}$ & $-\mathrm{ve}$ & $-\mathrm{ve}$ & $+\mathrm{ve}$ & $-\mathrm{ve}$ & $-\mathrm{ve}$ & $-\mathrm{ve}$ & $-\mathrm{ve}$ \\
\hline Indole & $+\mathrm{ve}$ & $+\mathrm{ve}$ & $-\mathrm{ve}$ & $-\mathrm{ve}$ & $-\mathrm{ve}$ & $-\mathrm{ve}$ & $-\mathrm{ve}$ & $-\mathrm{ve}$ \\
\hline MethylRed & $+\mathrm{ve}$ & $+\mathrm{ve}$ & $-\mathrm{ve}$ & $-\mathrm{ve}$ & $-\mathrm{ve}$ & $-\mathrm{ve}$ & $-\mathrm{ve}$ & $-\mathrm{ve}$ \\
\hline Urease & $-\mathrm{ve}$ & $-\mathrm{ve}$ & $-\mathrm{ve}$ & $-\mathrm{ve}$ & $-\mathrm{ve}$ & $-\mathrm{ve}$ & $-\mathrm{ve}$ & $-\mathrm{ve}$ \\
\hline Starch & $-\mathrm{ve}$ & $-\mathrm{ve}$ & $+\mathrm{ve}$ & $+\mathrm{ve}$ & $-\mathrm{ve}$ & $-\mathrm{ve}$ & $+\mathrm{ve}$ & $-\mathrm{ve}$ \\
\hline Glucose & AG & AG & - & A & - & AG & AG & AG \\
\hline Sucrose & - & A & A & - & - & - & AG & - \\
\hline Maltose & A & A & AG & A & - & A & AG & AG \\
\hline Lactose & AG & A & - & - & A & AG & AG & AG \\
\hline Fructose & - & A & AG & A & A & A & AG & AG \\
\hline Galactose & AG & AG & AG & - & - & AG & A & A \\
\hline
\end{tabular}

Key: A - Escherichia coli $\quad$ B - Staphylococcus aureus $\mathbf{C}$-Bacilus subtilis $\quad \mathbf{D}$-Bacilus cereus $\boldsymbol{E}$ - Streptococcus faecalis

$\mathbf{F}$-Lactobacilus plantarum $\boldsymbol{G}$-Leuconostoc mesenteriodes $H$-Lactobacillus fermentum $\mathrm{A}=$ Acid present and gas absent, $\mathrm{AG}=$ Acid and gas present, $-\mathrm{ve}=$ Negative,$+\mathrm{ve}=$ Positive, $-=$ Absent

Table.2 Morphological and biochemical characteristics of yeast isolated during fermentation of ripe plantain

\begin{tabular}{|l|l|l|}
\hline & A & B \\
\hline Cultural Characteristics & & \\
\hline Colour & Cream & Brown-black \\
\hline Size & Medium & Medium \\
\hline Surface & Smooth & Smooth \\
\hline Shape & Oval & Cylindrical \\
\hline Mycelium & + & + \\
\hline Sugar Fermentation & - & - \\
\hline Glucose & FA & \\
\hline Maltose & FA & FA \\
\hline Lactose & A & - \\
\hline Fructose & FA & FA \\
\hline Sucrose & FA & FA \\
\hline Galactose & FA & - \\
\hline
\end{tabular}

Key: A - Saccharomyces cerevisiae B - Candida utilis

$\mathrm{A}=$ Acid, $\mathrm{FA}=$ Fermentation and Assimilation, $-=$ Absent, $+=$ Present 
Table.3 Morphology and microscopy characteristics of mold isolates during fermentation of unripe plantain fruits

\begin{tabular}{|l|l|l|l|}
\hline Isolates & Cultural Characteristics & Spores/Conidia arrangement under the Microscope & $\begin{array}{l}\text { Identity of } \\
\text { Isolates }\end{array}$ \\
\hline A1 & $\begin{array}{l}\text { The surface is rough. Spores are granular flat, often } \\
\text { with radial grooves yellow at first but quickly become } \\
\text { bright yellow green with age. Sizes of colonies are } \\
\text { medium. }\end{array}$ & $\begin{array}{l}\text { Conidia are globose to sub globose with pale green colour. } \\
\text { Septate hyphae with long condiophore bearing the conidia }\end{array}$ & $\begin{array}{l}\text { Aspergillus } \\
\text { flavus }\end{array}$ \\
\hline $\mathbf{A 2}$ & $\begin{array}{l}\text { The surface is smooth with brown mycelia growth. } \\
\text { With whitish colonies large in size. }\end{array}$ & $\begin{array}{l}\text { An upright conidiopore that terminates in a swelling, } \\
\text { bearing phialides at the apex radiating from the entire } \\
\text { surface. Conidial are one celled and densely packed. } \\
\text { Spores are black. }\end{array}$ & $\begin{array}{l}\text { Aspergillus } \\
\text { niger }\end{array}$ \\
\hline A3 & $\begin{array}{l}\text { The surface is smooth. Dark greenish colour with white } \\
\text { boundaries on plates. }\end{array}$ & $\begin{array}{l}\text { Broom like structure with condioshpere bearing the } \\
\text { conodia }\end{array}$ \\
\hline
\end{tabular}


Table.4 The occurrence of bacteria and fungi during fermentation

Fermentation Period (day)

\begin{tabular}{|l|c|c|c|c|c|c|}
\hline & $\begin{array}{c}\text { Unfermented } \\
\text { Sample }\end{array}$ & $\mathbf{1}$ & $\mathbf{2}$ & $\mathbf{3}$ & $\mathbf{4}$ & $\mathbf{5}$ \\
\hline Escherichia coli & + & + & - & - & - & - \\
\hline $\begin{array}{l}\text { Staphylococcus } \\
\text { aureus }\end{array}$ & + & + & - & - & - & - \\
\hline Bacillus subtilis & + & + & + & - & - & - \\
\hline Bacillus cereus & + & + & - & - & - & - \\
\hline $\begin{array}{l}\text { Streptococcus } \\
\text { faecalis }\end{array}$ & - & + & + & + & - & - \\
\hline $\begin{array}{l}\text { Lactobacillus } \\
\text { plantarum }\end{array}$ & - & - & + & + & + & + \\
\hline $\begin{array}{l}\text { Lactobacillus } \\
\text { fermentum }\end{array}$ & - & - & - & + & + & + \\
\hline $\begin{array}{l}\text { Leuconostoc } \\
\text { mesenteriodes }\end{array}$ & - & - & - & + & + & + \\
\hline $\begin{array}{l}\text { Saccharomyces } \\
\text { cerevisiae }\end{array}$ & + & + & + & + & + & + \\
\hline Candida utilis & + & + & + & + & + & + \\
\hline \begin{tabular}{l} 
Aspergilus flavus \\
\hline Aspergilus niger
\end{tabular} & + & - & - & - & - & + \\
\hline Penicillum notatum & + & - & - & - & - & - \\
\hline
\end{tabular}

Table.5 Microbial screening for enzyme production

\begin{tabular}{|l|c|c|c|c|c|}
\hline Isolates & Amylase & Protease & Lipase & Pectinase & Cellulase \\
\hline Lactobacillus fermentum & + & + & - & - & - \\
\hline Bacillus subtilis & + & + & + & + & + \\
\hline Bacillus cereus & + & + & + & + & + \\
\hline Staphylococcus aureus & + & - & + & + & - \\
\hline Escherichia coli & + & + & + & - & - \\
\hline Lactobacillus plantarum & + & + & + & - & - \\
\hline Leuconostoc mesenteriodes & + & + & + & - & - \\
\hline Streptococcus feacalis & + & + & + & - & - \\
\hline Saccharomyces cerevisiae & + & + & + & + & + \\
\hline Candida albicans & + & + & + & - & - \\
\hline Aspergillus flavus & + & + & + & + & + \\
\hline Aspergillus niger & + & + & + & + & + \\
\hline Penicillium notatum & + & + & - & - & + \\
\hline
\end{tabular}

Legend: + Positive, - Absent 
Figure.1 Bacterial counts of sample during fermentation

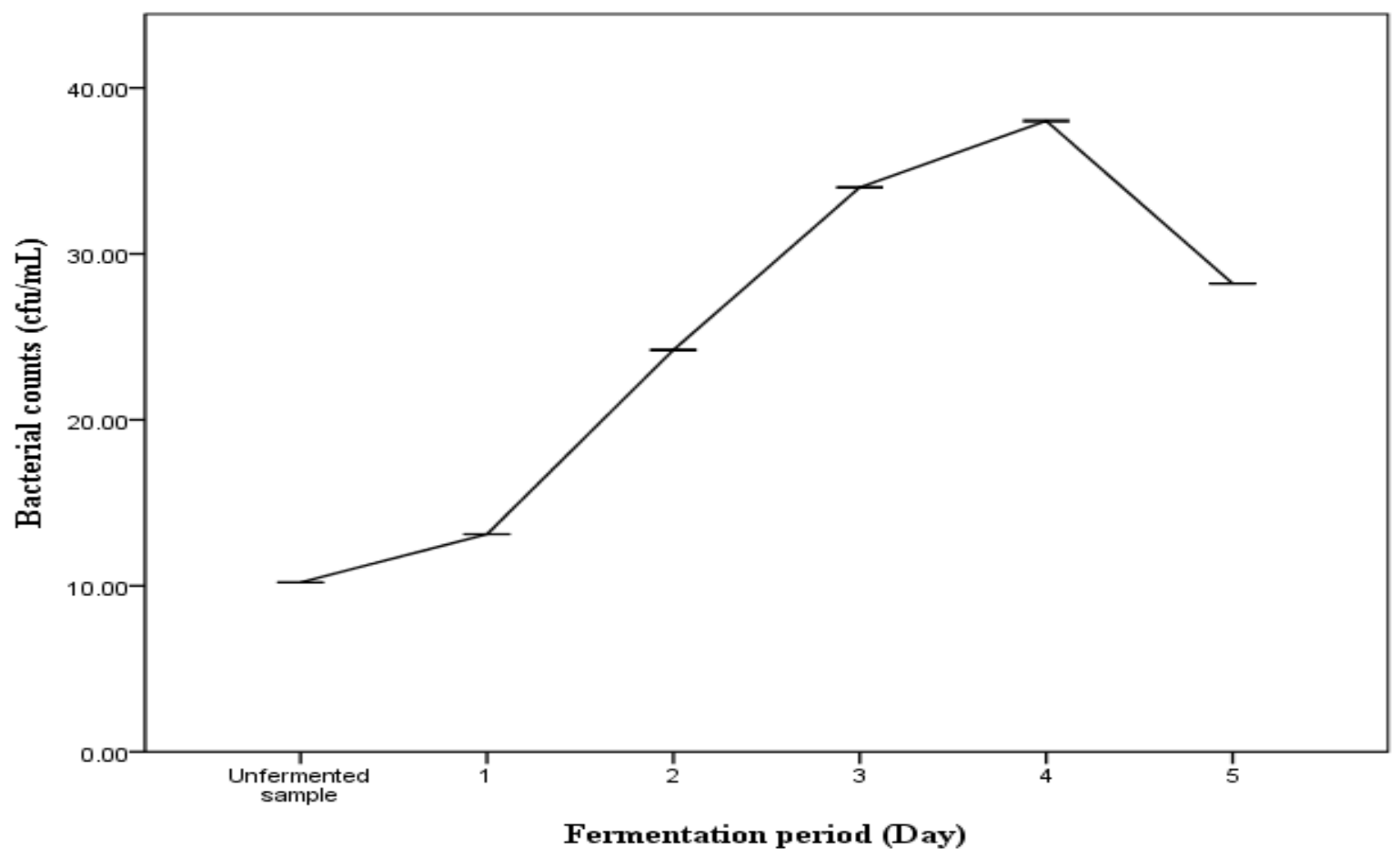

Figure.2 Fungal counts of sample during fermentation

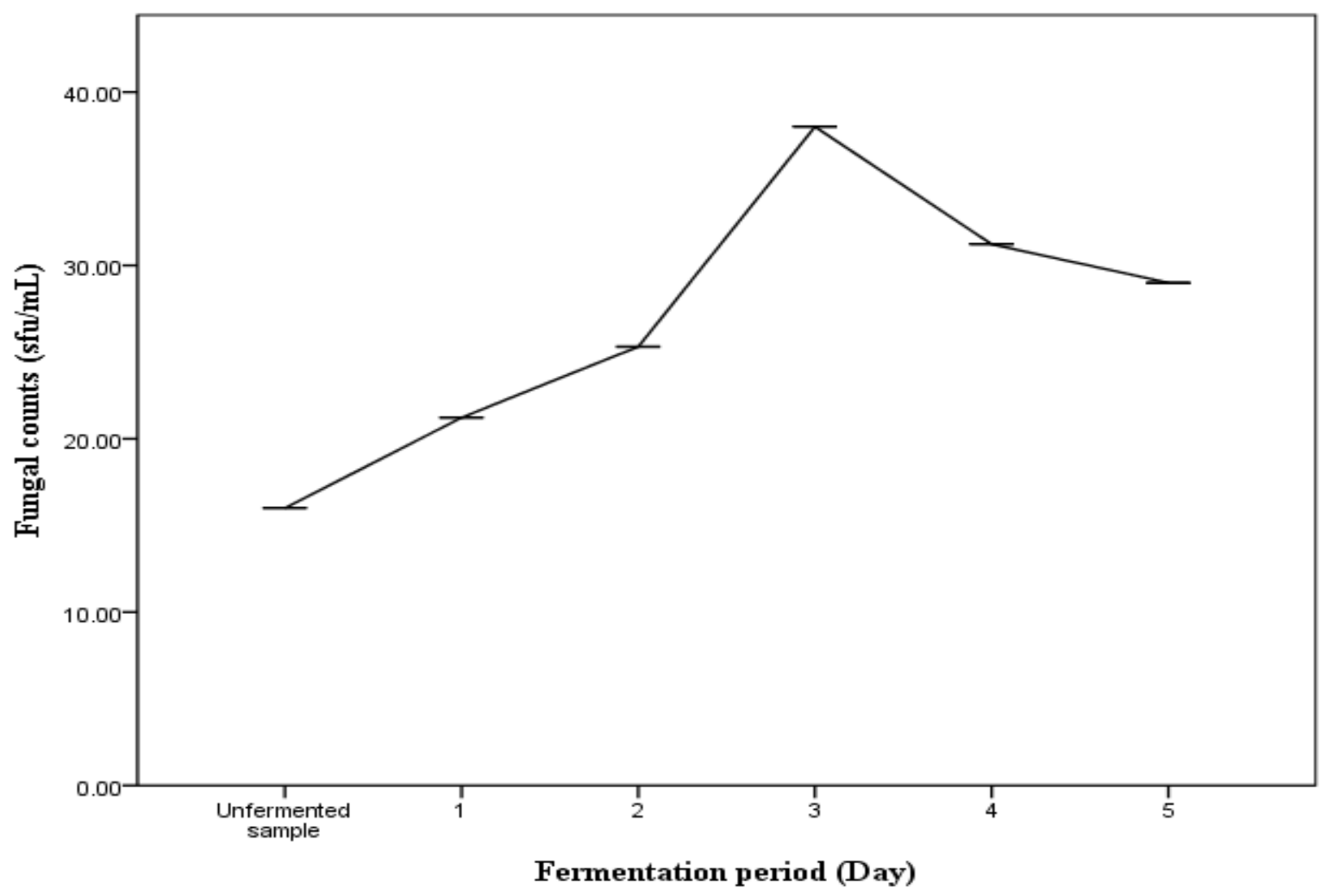


Figure.3 Enzyme activity of sample during fermentation

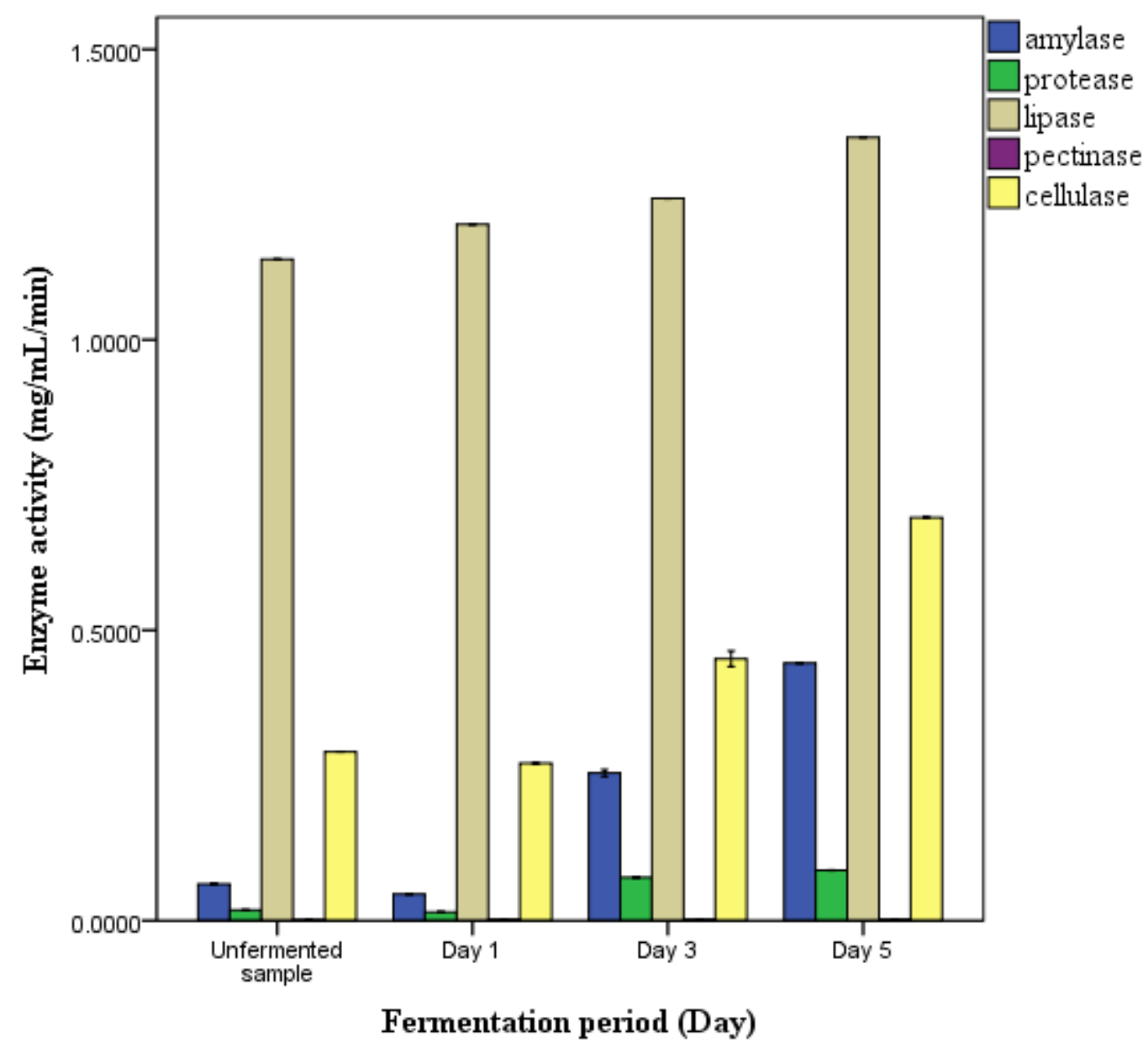

The growth and population of other microorganisms maybe due to the creation of enabling environment; which favour their survival and development of these set of microorganisms. These conform to the report of Ogbonnaya and Chukwu (2012).

Saccharomyces spp, could utilize the sugars present within the plantain fruits for the facilitation of the fermentation process in order to accumulate ethanol in the presence of oxygen particularly during early days of degradation period (Walker et al., 2016; Alonso-del-Real et al., 2017). However, S. cerevisiae becoming dominant on day 4 and 5 may be due to the environmental conditions that facilitate their survival, growth, development and proliferation. Candida spp, yeast catabolizes sugars into carbon dioxide in the presence of oxygen may create an enabling environmental condition which may have facilitated the occurrence of $S$. cerevisae during fermentation (Azhar et al., 2017).

The availability of light may be responsible for the growth of A. niger and A. flavus particularly in the unfermented sample, fermented sample of day 4 which also agrees with the findings of Shehu and Bello while studying the effect of environmental factors on the growth of Aspergillus spp. associated with stored grains (Shehu et al., 2012). Also, 
as the fermentation period increases, relative humidity and light intensity decreases. Thus, these factors could be applicable to bacteria and yeast that grew on the unfermented ripe plantain fruits.

Ripe plantain fruits could serve as a fermentation media for the production of enzymes. The production of enzymes by microorganisms in the fermentation media depend on the availability of suitable and utilizable substrate (Adeleke et al., 2017). More so, Rashid et al., (2016) concurred that major and minor elements contained within a substrate can be fermented or synthesized by microorganisms using various enzymes. Also, the capacity of microorganisms to produce extracellular enzymes is influenced by environmental conditions such as temperature, $\mathrm{pH}$, aeration, inoculums age and the presence of inducer or repressor substrates (Nigam, 2013). Solid state fermentation for the production of enzymes offers advantages over the conventional method of submerged fermentation (Cruz et al., 2013). Submerged method of fermentation used may also be attributed to the low enzyme activities (Colla et al., 2015).

The low amount of enzyme activity of all the enzymes assayed for particularly in the unfermented sample may be due to complex structure such as cellulose, hemicellulose and lignin which is important for its utilization and digestibility (Tejado et al., 2007; Cao et al., 2012; Li et al., 2016; Murali et al., 2017). The progressive increase in enzyme activities may be due to the hydrolytic (water) effect on the plantain fruits which may increase the surface area and remove hemicellulose. This is in agreement with the findings of Rodolfo (2014) that water treatments at elevated temperatures $\left(200-230^{\circ} \mathrm{C}\right)$ and pressures can increase the biomass surface area and remove hemicellulose. The enzyme activity of the plantain fruits may have increased if it temperature and pressure were raised. The presence of cellulase in plantain fruits agrees with the separate reports of Sethi et al., (2013) and Philip et al., (2016) which states that enormous amounts of agricultural, industrial and municipal cellulose wastes contains cellulose. The increased cellulase activity at the early period of fermentation could be due to the reduced amount of disaccharide cellobiose which could be present within fermented plantain fruits which seems to be a more potent inhibitor of cellulase (Gao et al., 2016). Payne et al., (2015) documented that a large number of compounds such as glucose, mannose, galactose, xylose, ethanol and various ions can act as possible inhibitor for cellulase.

The unfermented sample offered reduced accessibility to cellulose and hemicellulose and degradability for enzymatic or chemical action which agrees with the findings of Barakat et al., (2014) and Gao et al., (2016). The presence of Bacillus spp. may contribute to the production of cellulase in the plantain fruits during fermentation. Separate findings of Akhtar et al., (2012) and Saowapar et al., (2014) agrees with this finding when different species of Bacillus produced cellulase.

Aspergillus niger, and A. flavus that were positively screened for cellulase production agrees with the separate findings of Jabasingh (2011), Liu et al., (2011) and Amorea and Faracoa (2012) that A. acculeatus, A. fumigatus, $A$. niger were producers of cellulase. Yeasts such as S. cerevisae and Candida spp have shown capacity to produce cellulase (Maki et al., 2009). Lactobacillus spp being protease producers agrees with the finding of Hnin et al., (2015) that proteolytic activity is an important characteristic of lactic acid bacteria. Bacillus spp production of protease agrees with the findings of Hamza and Woldesenbet (2017) when Bacillus sp. Cab44 was observed to hydrolyse casein. 
Oyeleke et al., (2010) documented that $A$. flavus and A. fumigatus were able to produce extracellular protease. Oyeleke et al., (2010) observed that when A. flavus and A. fumigatus were subjected to the same temperature of $30^{\circ} \mathrm{C}$, A. flavus was able to produce the highest amount of protease. Fungi are better producers of pectinase when compared to bacteria based on the findings of this research. This agrees with different documentations of (Raju and Divakar 2013; Roosdiana et al., 2013; Kavuthodi et al., 2015 and Reddy et al., 2016) that most of the Bacterial isolates (mostly Bacillus spp and Pseudomonas spp) such as; Pseudomonas fluorescence and $B$. subtilis, Bacillus sp. MFW7, B. cereus and Staphylococcus aureus were reported as good pectinase producers. Bacillus subtilis being a producers of pectinase agrees with the report of Mariam and Aruna (2017) that B. subtilis strain arium 1115 produced the highest quantity of extracellular pectinase out of the arrays of Bacillus spp assayed for.

All bacterial isolates were able to break down soluble starch. Bacillius spp. were screened positive for all enzymes evaluated for. Bacills subtilis had the highest zone of clearance. The presence of these amylolytic bacterial in the soil agreed with an earlier report by Omemu et al., (2005) as cited by Oyeleke et al.,(2010), that soil is known to be a repository of amylase. The bacterial isolates of Bacillus spp. also showed a high ability to secrete pectinase with low ability to secrete protease. Although, Rodarte et al.., (2011) reported that Bacillus cereus did not show positive result in protease qualitative test. Staphylococcus aureusin this study did not show the ability to secrete protease and cellulose, this did not agree with the findings of Appak (2006) who stated that Staphylococcus spp. produced lipases and proteases more than any other enzyme group.

The various Bacillus spp isolated from the ripe plantain fruit sample was the best producer of lipase based on the zone of hydrolysis. Lactic acid bacteria isolated from the plantain fruits during fermentation exhibiting lipase activity concurred with the documentation of Padmapriya et al., (2011) that Lactobacillus spp is a producer of lipase. Candida albicans and A. flavus, screened positive for lipase production agrees with the documentation of Singh et al., (2016) that $C$. Antarctica, C. lipolytica and A. flavus are producers of lipase.

Fungi are better producers of pectinase when compared to bacteria based on the findings of this research. Bacillus spp. isolated were indicated to be a producer of pectinase. This agrees with different documentations of Raju and Divakar (2013); Roosdiana et al., (2013); Kavuthodi et al., (2015) and Reddy et al., (2016) that most of the Bacterial isolates (mostly Bacillus spp. and Pseudomonas spp.) such as; Pseudomonas fluorescence and $B$. subtilis, Bacillus sp. MFW7, B. cereus and Staphylococcus aureus were reported as good pectinase producers. Bacillus subtilis being a producers of pectinase agrees with the report of Mariam and Aruna (2017) that B. subtilis strain arium 1115 produced the highest quantity of extracellular pectinase out of the arrays of Bacillus spp assayed for. $\mathrm{pH}$ could also be a factor for low pectinase production in which acidic $\mathrm{pH}$ values were observed during the fermentation of the plantain fruits. According to the finding of Mariam and Aruna (2017), B. subtilis strain arium 1115 produced the highest amount of pectinase at pH $9(21.44 \mathrm{U} / \mathrm{mL})$. Temperature is another factor to consider for pectinase production. Bacillus species have demonstrated slightly higher temperature for pectinase production such as marine $B$. subtilis and $B$. circulans at $40^{\circ} \mathrm{C}$ (Joshi et al., 2013; Raju and Divakar, 2013). However, findings show $B$. cereus, $B$. firmus I-10104, B. cereus and B. endophyticus and $B$. coagulans exhibited maximum pectinase production at $37^{\circ} \mathrm{C}$ (Namasivayam et al., 2011; Aaisha and Barate, 2016). 
Amylase activity in the plantain fruits during fermentation may be as a result of the presence of concentration of hemicellulose carbohydrate particular starch within the plantain fruits. This agrees with the findings of Singh et al., (2012) when amylase and xylanase content of rice bran, corn cob, wheat bran, wheat straw, and sugarcane bagasse were described in relation with the composition of starch and hemicellulose. The progressive increase in amylase activity in the fermented plantain fruits could be due to the availability of microorganisms such as $B$. cereus, B. subtilis, Lactobacillus spp., A. flavus, $C$. albicans, and $S$. cerevisiae in the fermenting substrate. These consortiums of microorganisms may contribute to the high amylase production. Akpomie et al., (2012) reported that Bacillus spp and Lactobacillus sp have ability to produce amylase. Hence, Bacillus spp. are known to be commercial producer of amylase. Progressive increase in temperature could also be another factor that led to the progressive increase in amylase production which may be a satisfactory condition that made the microorganisms to produce more amylase. Akpomie et al., (2012) attested to this fact that gradual increase in amylase activity was observed from $26{ }^{\circ} \mathrm{C}$ to $45{ }^{\circ} \mathrm{C}$ and beyond this range it declined. Thus, temperature contributes to the factor responsible for the secretion of amylase.

It is concluded that microorganisms utilized ripe plantain fruits as substrate for production of some metabolites of industrial applications. Farmers needs to be oriented about the usefulness of plantain fruits for production of substances such as enzymes that are valuable in industries thus, can be applied for its biotechnological application in food, pharmaceutical and medical industries.

\section{References}

Adeleke, B.S., Olaniyi, O.O., Akinyele, B.J.
2017. Isolation and Screening of Bacteria Associated with Fermented Cassava Peels for Linamarase Production. Intl J Appl Biotechnol Res 5: 20-26.

Agbor, V.B., Cicek, N., Sparling, R. 2012. Biomass Pretreatment: Fundamentals toward Application. Biotechnology Advances, 29: 675-685.

Akhtar, N., Sharma A., Deka, D. 2012. Characterization of Cellulase Produced of Bacillus sp. for Effective Degradation of Leaf Litter Biomass. Environmental Progress and Sustainable Energy, 32: 1195-1201.

Akpomie, O.O., Akponah, E., Okorawhe, P. 2012. Amylase Production Potentials of Bacterial Isolates obtained from Cassava Root Peels. Agricultural Science Research Journals, 2(2): 95-99.

Alonso-del-Real, J., Lairón-Peris, M., Barrio, E., Querol, A. 2017. Effect of Temperature on the Prevalence of Saccharomyces Non cerevisiae Species against a $S$. cerevisiae Wine Strain in Wine Fermentation: Competition, Physiological Fitness, and Influence in Final Wine Composition. Front Micro 8: 150-198.

Amorea, A., and Faracoa, V. 2012. Potential of Fungi as Category I Consolidated Bioprocessing Organisms for Cellulosic Ethanol Production. Renew Sustained Energy Reviews, 16: 3286-3301.

AOAC. 2012. Guidelines for SingleLaboratory Validation of Chemical Methods for Dietary Supplements and Botanicals. Official Methods of Analysis, $19^{\text {th }}$ Edition, Appendix K, AOAC International, Gaithersburg, MD.

Apppak, S. 2006. Biochemical and molecular characterization of extracellular enzyme producing Staphylococci isolated from different origins. Master of Science thesis submitted to the graduate school 
of engineering and sciences of Zmir Institute of Technology, pp. 51.

Azhar, S.H.M., Siti, R.M., Jambo, A., Marbawi, H., Gansau, J.A. 2017. Yeasts in Sustainable Bioethanol Production: A review. Biochem Biophy Rep 10: 52 61.

Bajpai, P. and Bajpai, P.K. 1989. HighTemperature Alkaline $\alpha$-Amylase from Bacillus iicheniformis TCRDC-B13. Biotech Bioeng 33: 72-78.

Barakat, A., Mayer, C., Solhy, A., Arancon, R.A.D, De-Vries, H., Luque, R. 2014. Mechanical Pretreatments of Lignocellulosic Biomass: Towards Facile and Environmentally Sound Technologies for Biofuels Production. RSC Advances, 4:48109-48127.

Bernfeld, P. 1951. Amylase $a$ and $b$ in Methods in Enzymes. Academic Press, New York, 144-147.

Cao, S., Pu, Y., Studer, M., Wyman, C., and Ragauskas, A.J. 2012. Chemical Transformations of Populus trichocarpa During Dilute Acid Pretreatment. Royal Society of Chemistry Advances, 2:10925-10936.

Cheesbrough, M. 2010. District Laboratory Practice in Tropical Countries. Cambridge: Cambridge University Press.

Colla, L.M., Ficanha, A.M.M., Rizzardi, J. Bertolin, T.E., Reinehr, C.R. 2015. Production and Characterization of Lipases by Two New Isolates of Aspergillus through Solid-State and Submerged Fermentation. BioMed Res Intl 2015: 725-734.

Cruz, R., Fonseca, J.C., Fernandes, M.J.S., Lima, D.M.M., Duda, G.P. 2013. Diversity of

Filamentous Fungi of Area from Brazilian Caatinga and High-Level Tannase Production Using Mango (Mangifera indica L.) and Surinam Cherry (Eugenia uniflora L.) Leaves under SSF. Adv
Microbiol 3: 52-60.

Fawole, M.O., and Oso, B.A. 2007. Laboratory Manual Microbiology Spectrum Books Limited, Ibadan, Nigeria. pp. 23.

Food and Agriculture Organization. 2014. Faostat Database Collections; Food and Agriculture Organization of the United Nations: Rome, Italy.

Gao, D.M., Kobayashi, T., Adachi, S. 2016. Production of Keto-Disaccharides from Aldo-Disaccharides in Subcritical Aqueous Ethanol. Food \& Nutrition Science, 80(5): 998-1005.

Hamza, T.A., and Woldesenbet, F. 2017. Optimization of Culture Growth Parameters for Production of Protease from Bacteria, Isolaed from Soil. Bioscience and Bioengineering,3(1): 110.

Hankin, L., Zucker, M., Sands, D.C. 1971. Improved solid medium for the detection an enumeration of pectolytic bacteria. Applied Microbiology, 22: 205-209.

Hamid, M., and Ikram-ul-haq. 2008. Production of Alkaline Protease by Bacillus subtilis and its Application as a Depilating Agent in Leather Processing. PakJ Bot 40: 1673-1679.

Hasan, F., Shan, A.A., Hameed, A. 2006. Industrial Applications of Microbial Lipases. Enzyme Microb Technol 39: 235-251.

Hill, J., Nelson, E., Tilman, D., Polasky, S., Tiffany, D. 2006. Environmental, Economic, and Energetic Costs and Benefits of Biodiesel and Ethanol Biofuels. Pro Nat Acad Sci USA 314: 1598-1600.

Hnin, E., Zaw, K.O., Kyaw, N.A. 2015. Screening on proteolytic activity of lactic acid bacteria from various yogurts and fermented milk. International Journal of Advances in Science Engineering and Technology, 34-37. 
Jabasingh, S.A. 2011. Utilization of Pretreated Coir Pith for the Optimized Bioproduction of Cellulase by Aspergillus nidulans. Intl J Biodeterior Biodegrad 65: 1150-1160.

Joshi, M., Nerurkar, M., Adivarekar, R. 2013. Use of Citrus Limetta Peels for Pectinase Production by Marine Bacillus subtilis. Innovative Romanian Food Biotechnology, 12: 75-83.

Kalui, C.K., Mathara, J.M., Kutima, P.M. 2010. Probiotic Potential of Spontaneously Fermented Cereal Based Foods-A Review. African J Biotechnol 9: 2490-2498.

Kavuthodi, B., Thomas, S.K., Sebastian, D., Martinez-Sobrido, L., Mohamed, E.A. 2015. Co-Production of Pectinase and Biosurfactant by the Newly Isolated Strain Bacillus subtilis BKDS1. British Microbiology Research Journal, 10(2): 112-131.

Kiro, M. 2010. The Effects of Different Carbon Sources on Biosynthesis of Pectinolytic Enzymes by Aspergillus Niger. ATI - Appl Technol Innov 3: 23 29.

Kumar, D., Savitri, N., Thakur, R.V., Bhalla, T.C. 2008. Microbial Proteases and Application as

Laundry Detergent Additive. Microbiol 3: 661-672.

Ladd, J.N., and Butler, J.H.A. 1972. Shortterm Assay on Soil Proteolytic Enzyme Activity Using Proteins and Dipeptide Substrate. Soil Biol Biochem 4: 19-39.

Li, M., Pu, Y., Ragauskas, A.J. 2016. Current Understanding of the Correlation of Lignin Structure with Biomass Recalcitrance. Frontiers in Chemistry, 4: $1-8$.

Lisdiyanti, P., Suyanto, E., Gusmawati, N.F., Rahayu, W. 2012.Isolation and characterization of cellulose produced by cellulolytic bacteria from peat soil of Ogan Komering Ilir, South Sumatera.
International Journal of Environment and Bioenergy, 3: 145-153.

Liu, D., Zhang, R., Yang, X.H., Xu, D., Tang, Z., Shen, Q. 2011. Thermostable Cellulase Production of Aspergillus fumigatus $\mathrm{Z5}$ under Solid-State Fermentation and Its Application in Degradation of agricultural wastes. International Journal of Biodeterioration and Biodegradation, 65: 717-725.

Maia, M.D., Morais, C.D., Morais, A.D., Melo, H.M., Filho, J.L. 1999 Production of Extracellular Lipase by the Phytopathogenic Fungus Fusarium solani FS1. Rev Microbiol 30: 304-309.

Maki, M., Leung, K.T., Qin, W. 2009. The Prospects of Cellulase-Producing Bacteria for the Bioconversion of Lignocellulosic Biomass. International Journal of Biological Sciences, 5(5), 500-516.Intercept Lavoisier; pp. 349370.

Mandels, M., Andreotti, R., Roche, C. 1976. Measurements of saccharifying cellulase. Biotech Bioeng Symp 6: 2133.

Mariam, K., and Aruna, K. 2017. Optimization and Partial Characterization of Pectinase Produced by Bacillus subtilis strain arium 1115 Isolated from Spoilt Apple. International Journal of Recent Scientific Research, 8(8):19633-19644.

Mbajiuka, C.S., Obeagu, E.I., Chude, C.N., Ihezie, O.E. 2014. Antimirobial effects of Chromolaena odorata on some human pathogens International Journal of Current Microbiology and Applied Science,3(3): 1006-1012.

Miller, G.L. 1959. Use of Dinitrosalycilic Acid (DNSA) Reagent for the Determination of Reducing Sugar. Analyt Chem 31: 426-428.

Mukesh, K.D.J., Saranya, G.M., Suresh, K., Andal, D., Rajakumar, R., 
Kalaichelvan, P.T. 2012. Production and Optimization of Pectinase from Bacillus sp. MFW7 Using Cassava Waste. Asian Journal of Plant Science Research, 2: 369-375.

Munaya, C. 2013. Bitter leaf-based extracts cures hepatitis co-inferationand others. The Guardian Newspaper.

Murali, N., Srinivas, K., Ahring, B.K. 2017. Biochemical Production and Separation of Carboxylic Acids for Biorefinery Applications. Multidisciplinary Digital Publishing Institute. Fermentation, 3(22): 1-25.

Nasrin, S., Ansary, M.U., Alam, K.M. 2017. Optimization of Citric Acid Production by Substrate Selection using Gamma Ray Induced Mutant Strain of Aspergillus niger. Global Journal of Medical Research: C Microbiology and Pathology, 17(2): 22-30.

Nelson, S.C., Ploetz, R.C., Kepler, A.K. 2006. Musa species (bananas and plantains), ver. 2.2. In: Elevitch CR (ed.). Species Profiles for Pacific Island Agroforestry. Permanent Agriculture Resources.

Nigam, P. 2013. Microbial Enzymes with Special Characteristics for Biotechnological Applications. Biomolecules 3: 597-611.

Ogbonnaya, N., and Chukwu, B.C. 2012.Studies on Akamu, a Traditional Fermented Maize Food. Revista Chilena de Nutricion, 39(4): 180-185.

Omemu, A.M., Akpan, I., Bankole, M.O., Teniola, O.D. 2005. Hydrolysis of raw tuber starches by amylase of Aspergillus niger AMO7 isolated from the soil. African Journal of Biotechnology, 4(2): 342-344.

Oriola, O., Boboye, B., Adetuyi, F. 2017. Microorganisms associated with the production of a Nigerian Fermented Beverage, 'Agadagidi'. Microbiology Research Journal International 20(6): 1-9, Article no. MRJI.32654ISSN: 2456-
7043.

Osundahunsi, O.F. 2009. Scanning electron microscope study and pasting properties of unripe plantain. Journal of Food Agriculture and Environment, 7(3 and 4):182-186.

Oyeleke, S.B., Egwin, E.C., Auta, S.H. 2010. Screening of Aspergillus flavus and Aspergillus fumigatus strain for extracellular protease enzymes production. Journal of Microbiology and Antimicrobials, 2 (7): 83-87.

Padmapriya, B., Rajeswari, T., Noushida, E., Sethupalan, D.G., Venil, C.K. 2011. Production of Lipase Enzyme from Lactobacillus spp. and Its Application in the Degradation of Meat. World Appl Sci J 12: 1798-1802.

Payne, C.M.,Knott, B.C., Mayes,H.B., Hansson, M., Himmel, M.E., Sandgren, M., Ståhlberg, J., Beckham, G.T. 2015. Fungal Cellulases. Chemical Reviews, 115:1308-1448.

Philip, J., Tanuja, T., Bedi, S. 2016. Occurrence of Cellulose Degraders in Fruit and Vegetable Decaying Wastes. Bioremediation and Biodegradation, 7:6-10.

Raju, V.N.E., and Divakar, G. 2013. Production of Pectinase by Using Bacillus circulans Isolated from Dump Yards of Vegetable Wastes. International Journal of Pharmaceutical Science Research, 4(7): 2615-2622 and isolation of of celluloytic fungi from soils of Chittoor district, India. International Journal of Current Microbiology and Applied Sciences, 3 (7): 761 - 771.

Reddy, M.P.C., Saritha, K.V. 2016. Effects of the Culture Media Optimization on Pectinase Production by Enterobacter sp. PSTB-1, 3 Biotechnology, 6(2): 111.

Rodarte, M.R., Dias, D.R, Vilela, D.M., Schwan, R.F. 2011. Proteolytic 
activities of bacteria, yeast and filamentous fungi isolated from coffee fruit (Coffea Arabica L.) Acta scientiarum. Agronomy Maringa, 33(3): $457-464$.

Rodolfo, Q.R. 2014. Hydrolysis of Lignocellulosic Biomass. In Luis Augusto Barbosa Cortez (Coord.). Sugarcane bioethanol - R\&D for Productivity and Sustainability. Editora Edgard Blücher. São Paulo. pp. 717732.

Roosdiana, A., Prasetyawan, S., Mahdi, C. 2013. Production and Characterization of Bacillus firmus Pectinase. Journal of Pure and Applied Chemical Research, 2: 35-41.

Sangrila, S., and Tushar, K.M. 2013. Cellulase Production by Bacteria: A Review. British Microbiol Res J 3: 235258.

Saowapar, K., Yupa, P., Taweesak, T., Somboon, T. 2014. Screening and identification of cellulase producing bacteria isolated from oil palm meal. Journal of Applied Pharmaceutical Science, 4(4): 90-96.

Sethi, S., Datta, A., Gupta, B.L., Gupta, S. 2013. Optimization of Cellulase Production from Bacteria Isolated from Soil. ISRN Biotechnology, 2013: 985685-985709.

Shehu, K., and Bello, M.T. 2012. Effect of Environmental Factors on the Growth of Aspergillus species Associated with Stored Millet Grains in Sokoto. Nigerian J Bas Appl Sci 19: 218-223.
Singh, R., Kumar, M., Mittal, A., Mehta, P.K. 2016. Microbial Enzymes: Industrial Progress in 21st Century. 3Biotechnology, 6:174 - 188 .

Stresses, H., Schoofs, H., panis, B., Andre, E., Reynersnievs, K., Swennen, R. 2006. Development of Embrynogenesis cell suspensions from shoot meristematic tissues of 5. Banana and Plantain (Musa spp.) Plant Science. 170: $104-112$.

Tejado, A., Pena, C., Labidi, J., Echeverria, J.M., Mondragon, I. 2007. PhysicoChemical Characterization of Lignins from Different Sources for Use in Phenol-Formaldehyde Resin Synthesis. Bioresource Technology, 98: 16551663.

Toshi, W., and Sudhir, K.J. 2017. Isolation, Screening and Identification of Lipase Producing Fungi from Oil Contaminated Soil of Shani Mandir Ujjai. International J Curr Microbiol Appl Sci 6: 1872-1878.

Rachana, C. 2017. Isolation and Screening of Lipase Producing Bacteria from Oil Mill Effluent. Indian J Sci Res 13: 192194.

Rashid, M.I., Mujawar, L.H., Shahzad, T., Almeelbi, T., Ismail, I.M.I. 2016. Bacteria and Fungi Can Contribute to Nutrients Bioavailability and Aggregate Formation in Degraded Soils. Microbiol Res 183: 26-41.

Walker, G.M., and Stewart, G.G. 2016. Saccharomyces cerevisiae in the Production of Fermented Beverages. Beverages, 2: 30-41.

\section{How to cite this article:}

Mogaji, K.J. and Mogaji, O. 2020. Production of Microbial Enzymes from Ripe Plantain Fruits. Int.J.Curr.Microbiol.App.Sci. 9(06): 3835-3850. doi: https://doi.org/10.20546/ijcmas.2020.906.454 